О. В. Чорний, кандидат медичних наук, докторант кафедри публічного адміністрування Міжрегіональної Академії управління персоналом

\title{
ОСОБЛИВОСТІ РЕФОРМ У ДЕРЖАВНІЙ ПОЛІТИЦІ ОХОРОНИ ЗДОРОВ'Я В ЄВРОПЕЙСЬКИХ КРАЇНАХ У ТРАНСФОРМАЦІЙНИЙ ПЕРІОД: ІСТОРИЧНІ ТА СОЦІАЛЬНО-ЕКОНОМІЧНІ АСПЕКТИ
}

У статті зазначено, що держава повинна опікувати систему охорони здоров'я, що зумовлено вадами ринку медичних послуг і уявленнями про соиіальну справедливість. Люди повинні мати право на отримання принаймні деякого мінімуму медичної допомоги незалежно від рівня їхнього доходу, $і$ забезпечити таке право - обов'язок держави. Відповідно до основних засад державної політики майже у всіх країнах із розвиненою ринковою економікою були створені громадські системи охорони здоров'я, доступні для всіх або переважної більшості громадян.

Медичну допомогу в изих країнах надають як державні, так і недержавні медичні організації та індивідуально практикуючі лікарі. Амбулаторну допомогу надають лікарі загальної практики та фахівиі, що праиюють як індивідуальні підприємщі або в складі групових практик. Організації, подібні звичним для нас поліклінікам, зустрічаються лише в окремих країнах із розвиненою ринковою економікою.

Стаціонарне лікування здійснюють державні і недержавні лікарні, причому серед недержавних організацій є як некомериійні, так і комериійні. Співвідномення державних $і$ недержавних медичних організацій розрізняється в різних крайнах. Фінансування медичної допомоги населенню здійснюється або з бюджетних коштів держави, які формуються за рахунок загального оподаткування, або з коштів обов'язкового медичного страхування, які формуються за рахунок страхових внесків роботодавиів і внесків держави або пенсійних фондів за непращююче населення.

У системах бюджетного фінансування в європейських країнах кожен виробник знаходився в адміністративному підпорядкуванні певної територіальної одинииі. У системах страхового фінансування страховики не мали права самостійно вибирати виробників, які будуть надавати медичну допомогу застрахованим. Вони зобов'язані були укласти угоду про оплату медичної допомоги з будь-яким зацікавленим виробником медичних послуг.

Ключові слова: трансформаційний період, державна політика, реформи, історичні й сочіально-економічні аспекти, охорона здоров'я, європейські країни.

O. V. Chornyj. Features of reforms in public health policy in European countries in the transformation period: historical and socio-economic aspects

The article states that the state should take care of the health care system, due to the shortcomings of the medical services market and perceptions of social justice. People should have the right to receive at least some minimum medical care, regardless of their income level, and to ensure this right is the responsibility of the state. In accordance with the basic principles of public policy, in almost all countries with developed market economies, public health care systems have been established, accessible to all or the vast majority of citizens.

Medical care in these countries is provided by both public and private medical organizations and individual practitioners. Outpatient care is provided by general practitioners and specialists working as sole proprietors or as part of group practices. Organizations like our usual clinics are found only in some countries with developed market economies.

Inpatient treatment is provided by state and non-state hospitals, and among non-governmental organizations there are both non-profit and commercial ones. The ratio of public and private health organizations varies from country to country. Financing of medical care is carried out either from the state budget funds, which are formed at the expense of general taxation, or from the funds of obligatory medical insurance, which are formed at the expense of employers' insurance contributions and state or pension fund contributions for the unemployed population.

In the systems of budget financing in European countries, each producer was under the administrative subordination of a certain territorial unit. In insurance financing systems, insurers did not have the right to independently choose the manufacturers who will provide medical care to the insured. They were required to enter into a medical care agreement with any interested health care provider.

Key words: transformation period, public policy, reforms, historical and socio-economic aspects, health care, European countries.

Постановка проблеми. Головним завданням реформ охорони здоров’я, що розгорнулося у країнах з розвиненою ринковою економікою в 90-ті роки, стало стримування зростання державних витрат і підвищення ефективності систем охорони здоров'я [2]. Політика стримування витрат у європейських країнах проводилася за напрямками нормування споживання медичних послуг шляхом встановлення часу очікування їх надання та розвитку систем фінансового планування.

Реструктуризація медичного обслуговування полягала у скороченні кількості лікарняних ліжок у суспільній системі охорони здоров'я і заміщенні відносно більш дорогого стаціонарного лікування менш дорогим

(C) О. В. Чорний, 2020 
амбулаторним або первинним медично-санітарним обслуговуванням за допомогою розширення послуг денних стаціонарів та центрів амбулаторної хірургії, а також розширенні надання медичної допомоги на дому і розвитку фармацевтичного менеджменту.

Аналіз останніх досліджень і публікацій. При всьому різноманітті відмінностей між системами охорони здоров'я в європейських країнах всі вони, аж до 90-х років, характеризувалися спільністю принципів, на основі яких будувалися взаємодії між виробниками медичних послуг, медичними організаціями, індивідуально практикуючими лікарями та їх асоціаціями й організаціями, що їх фінансують. У європейських країнах зміцнилося розуміння того, що зазначені принципи взаємодії покупців і виробників медичних послуг є перешкодою для підвищення ефективності системи охорони здоров'я [9].

Державна політика поділу функцій фінансування і функцій прямого управління наданням послуг важлива для того, щоб рішення про розподіл виділених на охорону здоров’я бюджетних коштів не приймалося під впливом необхідності підтримувати підвідомчі медичні установи безвідносно до ефективності їх роботи. Розвиток конкуренції між покупцями за кращі медичні організації і за застрахованих, а також між виробниками за покупців і за пацієнтів має розглядатися як головна рушійна сила підвищення ефективності системи фінансування охорони здоров'я.

Метою статті $\epsilon$ вивчення досвіду європейських країн у трансформаційний період із реалізації реформ у державній політиці в системі охорони здоров'я.

Виклад основного матеріалу. У багатьох країнах передбачена співучасть населення в оплаті одержуваної медичної та лікарської допомоги, але частка приватних витрат у фінансуванні охорони здоров'я невелика, а співплатежі виконують роль обмежувача попиту. Розміри громадського фінансування охорони здоров’я в країнах із розвиненою ринковою економікою росли високими темпами. Однак нафтові кризи і уповільнення темпів економічного зростання поставили країни перед необхідністю шукати шляхи стримування зростання державних витрат на соціальні програми, зниження соціального навантаження на державу.

Водночас вимоги населення щодо якості роботи систем охорони здоров'я продовжували рости, європейські держави зіткнулися з неможливістю збільшувати колишніми темпами фінансові засоби, що направляються на охорону здоров'я, витрачати їх колишнім чином, тим самим забезпечувати зростання якості медичних послуг. Реформи, розпочаті в Нідерландах, у Великобританії, Німеччині, були спрямовані на впровадження елементів ринкових відносин у взаємодії між суб'єктами громадської охорони здоров'я.

У системах бюджетного фінансування охорони здоров’я територіальні органи управління охороною здоров’я не зобов’язані фінансувати тільки ті державні медичні організації, які розташовані на їх території, а могли укладати контракти на свій вибір лише з частиною з них, а також з недержавними організаціями і з організаціями, розташованими поза межами свого адміністративного утворення [7]. Державна політика в охороні здоров'я передбачає, що державні та недержавні медичні організації мають рівні права в системі громадського фінансування охорони здоров'я.

Виробники амбулаторно-поліклінічних послуг наділені правами часткового фондоутримування, вони мають можливість оплачувати послуги фахівців, проведення діагностики, а також частину видів стаціонарної допомоги.

Споживачі медичних послуг вільні у виборі лікарів і медичних організацій, а також у виборі страховиків у системах обов'язкового медичного страхування, незважаючи на введення внутрішнього ринку, у пацієнтів помітно не додалося можливостей вибирати лікарів і лікарень для отримання медичної допомоги.

Результати ринкових перетворень не були руйнівними для системи охорони здоров'я, як того побоювалися противники реформи, але і не виявилися настільки радикальними, щоб виправдати надії ії прихильників. Найбільш очевидними виявилися зміни в соціально-культурній складовій частині медичного обслуговування, підвищився соціальний статус лікарів загальної практики, посилилася увага до них з боку органів управління охороною здоров’я, менеджерів і лікарів, що працюють у стаціонарах [5]. Завдяки укладенню контрактів між отримувачами і виробниками медичних послуг останні стали краще розуміти, які види медичної допомоги вони повинні надавати, кому, за якими стандартами і за якою ціною.

Головна проблема реформ полягала в тому, що органи управління охороною здоров'я не стали незалежними покупцями медичних послуг, а лікарняні трасти - самостійними виробниками. Територіальні органи охорони здоров’я перебували під сильним тиском політиків, які обмежували їх у прийнятті будь-яких радикальних рішень щодо перерозподілу фінансування на користь більш ефективних виробників. Лікарняні трасти не мали стимулів до ведення конкурентної боротьби, оскільки, з одного боку, не мали можливості на власний розсуд розпоряджатися коштами, які могли у них з'явитися в разі успішної роботи, а також були впевнені, що їх врятують від банкрутства.

Використанню контрактних відносин для більш ефективного розподілу коштів перешкоджало небажання покупців медичних послуг вносити істотні зміни у сформовані структуру і обсяги медичної допомоги, що надається виробниками, щоб не порушити відносини довіри, професійну етику, не ризикувати довготривалою співпрацею. Проведення ринково орієнтованих реформ мало очевидні позитивні результати з політичної точки зору, вони 
надали імпульс діяльності органів охорони здоров’я, активізували їхні зусилля з регулювання надання медичної допомоги в інтересах населення, а не в інтересах самих лікарів і медичних організацій.

Конкуренція не скасовувалася повністю, але пріоритет тепер віддавався розвитку співробітництва між покупцями і виробниками медичних послуг: впровадження процедур спільного планування та укладання довгострокових контрактів замість щорічних [3]. Витрати, пов'язані з щорічним укладенням договорів, розцінювалися як занадто високі в порівнянні з підвищенням ефективності медичного обслуговування. Важливою складовою частиною проведених у західних країнах перетворень були зміни форм і правочинів медичних організацій, що беруть участь у системі охорони здоров’я.

Штатний розклад, умови оплати праці працівників, детальний бюджет цих установ затверджувалися вищими органами управління, метою змін було створення можливостей і стимулів для медичних організацій раціонально господарювати, створення умов для розвитку конкуренції між виробниками медичних послуг у системі охорони здоров’я. Для розширення прав державних медичних установ за розпорядженням фінансовими і матеріальними ресурсами в останні десятиліття у багатьох країнах проводилася державна політика надання більшої автономії державним медичним установам.

Відповідно, обмежувалися права адміністративного управління медичними установами з боку органів державного управління, а керівникам медичних організацій надавалися права самостійного прийняття оперативних рішень щодо розпорядження фінансовими і матеріальними ресурсами. Розширювалися права керівників установ 3 визначення умов роботи і оплати праці персоналу, це поєднувалося з впровадженням контрактних форм відносин між медичними установами та органами, що їх фінансують, а також із заміною кошторисного фінансування різними формами оплати результатів роботи цих установ. Але економічна самостійність, що надається медичним закладам, була обмеженою: установи, як і раніше, не несли повної економічної відповідальності за результати своєї роботи.

У разі недостатності в них коштів для покриття заборгованостей постачальникам товарів і послуг відповідачем за зобов’язаннями виступали державні органи управління [1]. У низці країн відбулися якісні зміни організаційно-правових форм, в рамках яких існують державні медичні організації. Метою реформи проголошувалося створення умов для розвитку конкуренції між виробниками медичних послуг і підвищення ефективності їх діяльності. Для цього медичні організації, підпорядковані територіальним органам управління охороною здоров'я, були перетворені в автономні державні підприємства охорони здоров'я.

Зазначені організації були засновані відповідно до моделі державного підприємства, єдиної для всієї економіки, вони мають право укладати контракти з персоналом, залучати капітал і діяти незалежно. Держава уповноважена стежити, щоб вироблені перетворення не привели до звуження кола споживачів послуг цих організацій і погіршення доступності медичної допомоги для будь-яких категорій населення, а також до порушень і розривів в технологічно пов'язаних видах медичного обслуговування [10]. У європейських країнах реформування охорони здоров’я розглядалося в якості однієї з важливих складових частин широкомасштабних економічних перетворень.

Повільне впровадження нових медичних технологій, препаратів і оновлення медичного обладнання, дефіцит лікарських засобів, низька заробітна плата лікарів і медичних сестер, що породжує тіньові платежі за їхні послуги, нерівність у доступності медичної допомоги, зумовлена соціальним статусом, - все це викликало надзвичайно критичне ставлення з боку як населення, так і медичних працівників. Система охорони здоров'я функціонувала також неефективно через недостатню забезпеченість лікарів медичним обладнанням у порівнянні із західними країнами.

Шляхи вирішення проблем недостатності бюджетних асигнувань, що виділяються на охорону здоров'я, неефективності використання наявного ресурсного потенціалу, зростаюче відставання від західноєвропейських країн за показниками стану здоров’я населення щодо розвитку і застосування медичних технологій бачиться в кардинальній зміні системи управління та фінансування охорони здоров'я [8]. У країнах із перехідним станом економіки реформи в охороні здоров'я були викликані розумінням неможливості зростання суспільного фінансування цієї сфери колишніми темпами у відповідь на зростаючі вимоги населення до якості медичного обслуговування.

Це зумовило спрямованість здійснюваних перетворень на підвищення ефективності системи охорони здоров'я. У європейських країнах реформи були породжені усвідомленням неможливості поліпшити якість медичного обслуговування, розраховуючи тільки на асигнування з державного бюджету. Реформи стали вираженням прагнення збільшити фінансування охорони здоров'я шляхом розширення джерел надходження коштів та зміни структури фінансових потоків. Вирішальний вплив на вибір страхових моделей фінансування загальної спрямованості перетворень зробила криза ідеології державного управління економікою і соціальною сферою.

Домінуюча роль держави в організації охорони здоров’я асоціювалася з колишнім ладом, і тому в нових політичних лідерів і в лікарської спільноти як реакція на минулий досвід державного управління запанувало бажання піти якомога далі від будь-якого державного втручання в систему охорони здоров’я. Заміна попередньої ідеології на ринкову визначила орієнтацію реформ в охороні здоров'я на запозичення моделей організації охорони здоров'я, які використовуються у країнах із розвиненою ринковою економікою. Причому інтерес був звернений до новітніх моделей фінансування охорони здоров'я, які починали впроваджуватися в Західній Свропі. 
Ліберальні уявлення про універсальні цінності ринкових принципів організації виробництва товарів і послуг затушували відмінності в причинах і умовах реформування. Це розцінювалося як реальний шлях отримання нових гарантованих джерел фінансування і як дієвий засіб підвищення ефективності системи медичного обслуговування [6]. Для формування фінансових коштів обов'язкового медичного страхування в більшості країн були введені обов'язкові внески на медичне страхування і для роботодавців, і для працівників. Усюди фонди медичного страхування $\epsilon$, як правило, квазідержавними організаціями, автономними по відношенню до державного бюджету і міністерства фінансів, хоча міра цієї автономії неоднакова.

У більшості країн територіальні відділення фондів монопольно виконують функції страховиків і покупців медичних послуг для всього населення, що проживає на відповідній території. Страховики не можуть змінювати розміри страхових внесків: вони визначаються державою. Для вирівнювання економічних умов роботи страховиків передбачений спеціальний фінансовий механізм. Частина внесків страховиків в обов'язковому порядку зараховується на спеціальний рахунок центрального фонду і потім перерозподіляється між усіма страховиками за певною формулою, що враховує стать і вік застрахованих.

Приватизація медичних і фармацевтичних організацій була одним із напрямків реформування охорони здоров’я, яке спочатку декларувалося практично у всіх європейських країнах. Приватизація медичних послуг у перехідних економіках здійснювалася більш швидко у фармацевтичній і стоматологічної напрямах [4]. Широкомасштабної приватизації лікарень і поліклінік у країнах Східної Свропи не відбулося, перш за все, тому, що вона суперечила інтересам основної маси медичних працівників, які боялися втратити державне фінансування.

Висновки 3 дослідження і перспективи подальших розвідок у цьому напрямі. У цілому результати реформ у європейських країнах поки що важко оцінити однозначно і тим більше узагальнити, більш певні висновки можна сформулювати стосовно процесу здійснення цих реформ, що мали низку спільних рис у деяких країнах. Прийняттю рішень щодо необхідності реформ передувало нагнітання засобами масової інформації в суспільній свідомості уявлень про кризовий стан охорони здоров'я. Бажання замінити старі інститути державного регулювання не супроводжувалося серйозним раціональним аналізом можливих альтернатив.

Упередження щодо державної системи фінансування, ментальна спадщина минулого створювали значні труднощі для пошуку раціональних рішень. Реформи в охороні здоров’я європейських країн були недостатньо продумані, була відсутня послідовність і узгодженість дій різних суб’єктів реформування. Відповідно до такої державної політики обов'язки державних органів управління були скорочені, але в більшості випадків при цьому не були створені альтернативні механізми для координації управління системами охорони здоров'я. Реформування охорони здоров’я відбувалося в умовах проведення масштабних економічних і політичних реформ, і несумісність з успішністю зазначених реформ породжувала проблеми для охорони здоров'я.

\section{Список використаних джерел:}

1. Войтович Р.В. Вплив глобалізації на систему державного управління (теоретико-методологічний аналіз) : монографія / за заг. ред. д-ра філос. наук, проф. В.М. Князєва. Київ : Вид-во НАДУ, 2007. 680 с.

2. Державна політика у сфері охорони здоров'я : кол. моногр. : у 2 ч. / кол. авт. ; упоряд. Я.Ф. Радиш; передм. та заг. ред. М.М. Білинської, Я.Ф. Радиша. Київ : НАДУ, 2013. Ч. 1. 396 с.

3. Карамишев Д.В. Стратегічне управління інноваційними процесами в системі охорони здоров'я: державні механізми : монографія. Харків : Вид-во ХарРІ НАДУ «Магістр», 2006. 224 с.

4. Кравченко М.В. Система соціального захисту населення як об’єкт державної політики: методологія та практика: монографія. Київ : Інформ.-аналіт. агентство, 2012. 451 с.

5. Крентовська О. Глобальна соціальна політика і міжнародне співробітництво щодо питань старіння населення. Демократичне врядування: науковий вісник. 2009. Вип. 4. URL: http://lvivacademy.com/ vidavnitstvo_1/visnik4/fail/+Krentovska.pdf (дата звернення: 15.08.2020).

6. Кризина Н.П. Державна політика України в галузі охорони здоров’я: генезис, тенденції та закономірності розвитку : монографія. Київ : Вид-во НАДУ, 2007. 224 с.

7. Лаврентій Д.С. Механізм державно-приватного партнерства в процесі реформування сфери охорони здоров’я в Україні : автореф. дис. ... канд. наук з держ. упр. : спец. 25.00 .02 «Механізми держ. упр.» ; М-во освіти і науки України, ПАТ «Вищ. навч. закл. «Міжрегіон. акад. упр. персоналом». Київ, 2019. 20 с.

8. Москаленко В.Ф., Грузєва Т.С., Іншакова Г.В. Регламентація права на охорону здоров’я у міжнародних нормативно-правових актах. Медичне право України: правовий статус пацієнтів в Україні та його законодавче забезпечення (генезис, розвиток, проблеми і перспективи вдосконалення) : матеріали II Всеукраїнської наук.-практ. конф. ( Львів, 17-18 квітня 2008p.). Львів. URL : http://medicallaw.org.ua/uploads/media/02_186_01.pdf ( дата звернення: 15.08.2020).

9. Охрана здоровья и права человека: ресурсное пособие / под научн. ред. И.Я. Сенюты (версия на рус. языке). 5-е изд., доп. Львов : Издательство ЛОБФ «Медицина и право», 2015. 989 с.

10. Палас Н. Транснаціональна модель демократії та іiі вплив на процеси глобального врядування в умовах сучасного світу. Украӥнська національна ідея: реалії та перспективи розвитку: зб. наук. пр. / Національний університет «Львівська політехніка» та ін. Львів : Вид-во НУ «Львівська політехніка», 2009. Вип. 21. С. $145-150$. 


\section{References:}

1. Voytovych R.V. (2007), Vplyv hlobalizatsiyi na systemu derzhavnoho upravlinnya (teoretyko-metodolohichnyy analiz) [Influence of globalization on the system of public administration (theoretical and methodological analysis)], Monograph. Press NADU, Kyiv, 680 p. [Ukraine]

2. Edited by Bilyns'koyi M.M., Radysha Ya.F. (2013), Derzhavna polityka u sferi okhorony zdorov'ya [State policy in the field of health care], Col. Monograph, 2 p., Press NADU, Kyiv, P. 1. 396 p. [Ukraine]

3. Karamyshev D.V. (2006), Stratehichne upravlinnya innovatsiynymy protsesamy v systemi okhorony zdorov'ya: derzhavni mekhanizmy [Strategic management of innovation processes in the health care system: state mechanisms], Monograph,. Press KharRI NADU «Mahistr», Kharkiv, 224 p. [Ukraine]

4. Kravchenko M.V. (2012), Systema sotsial'noho zakhystu naselennya yak ob'yekt derzhavnoyi polityky: metodolohiya ta praktyka [The system of social protection as an object of state policy: methodology and practice], Monograph, Press Inform.-analit. ahentstvo, Kyiv, 451 p. [Ukraine]

5. Krentovs'ka O. (2009), "Hlobal'na sotsial'na polityka i mizhnarodne spivrobitnytstvo shchodo pytan'starinnya naselennya" ["Global Social Policy and International Cooperation on Aging"], journal Demokratychne vryaduvannya [Democratic governance], vol. 4. URL : http://lvivacademy.com/vidavnitstvo_1/ visnik4/fail/ +Krentovska.pdf [Ukraine]

6. Kryzyna N.P. (2007), Derzhavna polityka Ukrayiny v haluzi okhorony zdorov'ya: henezys, tendentsiyi ta zakonomirnosti rozvytku [State policy of Ukraine in the field of health care: genesis, trends and patterns of development], Monograph, Press NADU, Kyiv, 224 p. [Ukraine]

7. Lavrentiy D.S. (2019), Mekhanizm derzhavno-pryvatnoho partnerstva v protsesi reformuvannya sfery okhorony zdorov'ya v Ukrayini [The mechanism of public-private partnership in the process of health care reform in Ukraine], Ph.D thesis: 25.00.02 „Mekhanizmy derzh. upr.”; press M-vo osvity i nauky Ukrayiny, PAT «Vyshch. navch. zakl. „Mizhrehion. akad. upr. Personalom”, Kyiv, 20 p. [Ukraine]

8. Moskalenko V.F., Hruzyeva T.S., Inshakova H.V. (2008), “Rehlamentatsiya prava na okhoronu zdorov'ya u mizhnarodnykh normatyvno-pravovykh aktakh" ["Regulation of the right to health care in international regulations"], materials of the II All-Ukrainian science-practict. conf. Medychne pravo Ukrayiny: pravovyy status patsiyentiv $v$ Ukrayini ta yoho zakonodavche zabezpechennya (henezys, rozvytok, problemy i perspektyvy vdoskonalennya) [Medical law of Ukraine: legal status of patients in Ukraine and its legislative support (genesis, development, problems and prospects for improvement)], Lviv. URL: http://medicallaw.org.ua/uploads/media/ 02_186_01.pdf [Ukraine]

9. Edited by Senyuty I.Ya. (2015), Okhrana zdorov'ya i prava cheloveka [Health protection and human rights], Resource manual, Press LOBF “Meditsina i pravo", Lviv, 989 p. [Russian]

10. Palas N. (2009), “Transnatsional'na model' demokratiyi ta yiyi vplyv na protsesy hlobal'noho vryaduvannya v umovakh suchasnoho svitu" ["Transnational model of democracy and its impact on the processes of global governance in the modern world"], collection of scientific works. Ukrayins 'ka natsional'na ideya: realiyi ta perspektyvy rozvytku [Ukrainian national idea: realities and prospects of development], Press NU «L'vivs'ka politekhnika», vol. 21, pp. 145-150 [Ukraine] 